\title{
Peningkatan Minat Belajar Siswa Menggunakan Metode Simon Berkata Pada Tema Selalu Berhemat Energi Kelas IV Sekolah Dasar Negeri 11 Sandung
}

\author{
Dwi Asih ${ }^{1}$, Dwi Cahyadi Wibowo *2 ${ }^{\text {, Agusta Kurniati }}{ }^{3}$ \\ 1,2,3 STKIP Persada Khatulistiwa Sintang \\ ‘dwicahyadiwibowo@gmail.com
}

\begin{abstract}
Abstrak
Tujuan umum dalam penelitian ini adalah untuk mendeskripsikan peningkatan Minat Belajar Siswa Menggunakan Metode Simon Berkata Pada Tema Selalu Berhemat Energi Kelas IV SD Negeri 11 Sandung Kecamatan Binjai Hulu Kabupaten Sintang Tahun Pelajaran 2018/2019. Metode penelitian menggunakan metode penelitian deskriptif kualitatif, dan bentuk penelitiannya menggunakan penelitian tindakan kelas. Subjek penelitian ini adalah siswa Kelas IV yang berjumlah 11 siswa dan guru. Teknik dan alat pengumpulan data menggunakan observasi, pengukuran, wawancara dan dokumentasi. Hasil penelitian ditemukan bahwa penggunaan metode Simon Berkata di Kelas IV SD Negeri 11 Sandung dapat meningkatkan minat belajar siswa, di mana siswa terlihat memiliki antusias yang baik dalam pembelajaran. Sedangkan dari faktor guru meningkatkan kinerja dan profesionalisme guru; aktivitas siswa mengalami peningkatan keantusiasan dalam belajar dan minat belajar yang sangat baik, penggunaan metode Simon Berkata pada siswa kelas IV SD Negeri 11 Sandung dikategorikan sangat baik yaitu siklus I, Ketuntasan $18.18 \%$ dan pada siklus II, klasikal $100 \%$ sehingga terjadi peningkatan sebesar $81.82 \%$, hal ini menunjukkan bahwa metode Simon Berkata mampu menjadi sebuah sarana yang menghantar pada pengembangan minat belajar siswa.
\end{abstract}

Kata Kunci: Minat Belajar Siswa, Metode Simon Berkata

\section{Pendahuluan}

Era globalisasi bangsa Indonesia bertekad untuk mengembangkan budaya belajar menjadi prasyarat berkembangnya budaya ilmu pengetahuan dan teknologi (IPTEK). Dalam mengembangkan budaya tersebut, perlu diupayakan dan diwujudkan cara dan bentuk belajar yang dapat diterapkan. Hal ini karena secara tersirat, persoalan - persoalan itu seharusnya menjadi rujukan dalam membahas masalah - masalah belajar. Dalam keseluruhan proses pendidikan di sekolah, kegiatan belajar merupakan kegiatan yang paling pokok. Ini berarti bahwa berhasil tidaknya pencapaian tujuan pendidikan banyak bergantung pada proses belajar yang dialami siswa sebagai anak didik. Belajar merupakan suatu proses perubahan, yaitu perubahan tingkah laku sebagai hasil dari interaksi dengan lingkungannya dalam memenuhi kebutuhan hidupnya.

Proses belajar siswa dipengaruhi oleh banyak faktor. Oleh karena itu, siswa harus mengetahui faktor - faktor yang dimaksud, demikian juga para pendidik, pembimbing, dan pengajar di dalam mengatur dan mengendalikan faktor - faktor yang memengaruhi belajar mengajar sehingga proses belajar mengajar berjalan menjadi optimal. Ada tiga mainstream 
yang perlu disoroti, yaitu pembaharuan kurikulum, peningkatan kualitas pembelajaran dan efektivitas pembelajaran. Kurikulum pendidikan harus komprehensif terhadap dinamika sosial, relevan, tidak overload, dan mampu mengakomodasikan keberagaman keperluan dan kemajuan teknologi. Kualitas pembelajaran harus ditingkatkan untuk memperbaiki kualitas hasil pendidikan. Secara mikro, harus ditemukan strategi atau pendekatan pembelajaran yang efektif di kelas, yang lebih memberdayakan potensi siswa. Ketiga hal ini, harus diterapkan secara stimulan dan seimbang jika kita ingin SDM ke depan lebih baik.

Sebagian besar metode dan suasana pengajaran di sekolah - sekolah yang digunakan para guru, tampaknya lebih banyak menghambat dalam memotivasi potensi otak. Misalnya, seorang peserta didik hanya disiapkan sebagai seorang anak yang mau mendengarkan, mau menerima seluruh informasi, dan menaati segala perlakuan gurunya. Budaya dan mental yang seperti ini, pada gilirannya membuat siswa tidak mampu mengaktivasi kemampuan otaknya sehingga mereka tidak memiliki keberanian menyampaikan pendapat, lemah penalaran, dan bergantung kepada orang lain. Budaya mental yang seperti ini berdampak pada budaya mental masyarakat secara luas, yaitu masyarakat kita yang belum bisa berpikir secara mandiri, walaupun belum bisa dipastikan budaya yang seperti ini, bermula dari sekolah atau justru sekolah dipengaruhi masyarakat luar. Akan tetapi, yang pasti semuanya saling mendukung untuk menyuburkan budaya tersebut.

Tugas guru dalam rangka optimalisasi proses belajar mengajar adalah sebagai fasilitator yang mampu mengembangkan kemauan belajar siswa, mengembangkan kondisi belajar yang relevan agar tercipta suasana belajar secara wajar dengan penuh kegembiraan, dan mengadakan pembatasan positif terhadap dirinya sebagai seorang guru. Jadi, metode pembelajaran merupakan salah satu faktor atau komponen pendidikan yang sangat menentukan berhasil - tidaknya suatu pembelajaran.

Seorang guru harus bisa membimbing, mengarahkan, dan menciptakan kondisi belajar siswa. Untuk mencapai hal tersebut, ia harus berusaha mengurangi metode ceramah dan mulai mengembangkan metode lain yang dapat melibatkan siswa secara aktif. Hal ini karena belajar aktif dapat dilihat dari dua segi, yaitu : (1) Dari segi siswa yang berarti bahwa belajar aktif merupakan proses kegiatan yang dilakukan siswa dalam rangka belajar. Aktivitas ini dapat berupa aktivitas fisik, mental, maupun keduanya, (2) Ada juga yang lebih menekankan pada keaktifan mental meskipun untuk mencapai maksud ini dipersyaratkan keterlibatan langsung berbagai keaktifan fisik.

Guru adalah variabel bebas yang memengaruhi kualitas pengajaran. Hal ini karena guru adalah sutradara dan sekaligus aktor dalam proses pengajaran. Kompetensi profesional yang dimiliki guru sangat dominan memengaruhi kualitas pembelajaran. Kompetensi adalah kemampuan dasar yang dimiliki guru. Baik bidang kognitif (intelektual), seperti penguasaan bahan, bidang, sikap, seperti mencintai profesinya, dan bidang perilaku, seperti keterampilan mengajar, penggunaan metode - metode pembelajaran, menilai hasil belajar siswa, dan lain lain. Di samping guru, faktor yang memengaruhi kualitas pembelajaran adalah penggunaan metode pengajaran. Metode mengajar adalah suatu cara atau jalan yang harus dilalui dalam mengajar. Mengajar adalah menyajikan bahan pelajaran oleh seseorang kepada orang lain agar orang lain itu menerima, menguasai, dan mengembangkan bahan pelajaran itu, guru harus mengajar dengan cara yang tepat, efisien, dan efektif.

Jelas bahwa metode mengajar memengaruhi kualitas pembelajaran. Metode mengajar guru yang baik, akan memengaruhi belajar siswa yang baik pula. Metode mengajar yang kurang baik dapat terjadi, misalnya karena guru kurang persiapan dan kurang menguasai bahan 
pelajaran sehingga cara penyajiannya tidak jelas atau sikap guru terhadap siswa dan mata pelajaran itu tidak baik sehingga siswa kurang senang terhadap pelajaran atau gurunya. Akibatnya, siswa malas untuk belajar.

Kesimpulan uraian di atas, ada kaitan eratnya dengan penelitian penulis yang berjudul "Peningkatan Minat Belajar Siswa Menggunakan Metode Simon Berkata Pada Tema Selalu Berhemat Energi Kelas IV Sekolah Dasar Negeri 11 Sandung Kecamatan Binjai Hulu Kabupaten Sintang Tahun Pelajaran 2018 / 2019". Minat belajar siswa dapat dilihat dari nilai ulangan tengah semester yang menunjukkan masih rendahnya minat belajar siswa pada pembelajaran tematik. Artinya aspek kognitif siswa tergolong rendah sehingga menyebabkan kualitas dalam proses dan cara pembelajaran yang dinilai konvensional dengan menerapkan metode pembelajaran yang umum digunakan. Kita ketahui bahwa pembelajaran tematik yang terdapat tema - tema pembelajaran. Di mana tiap - tiap tema berisikan beberapa mata pelajaran yang telah dilakukan pemetaan, oleh karena itu, pembelajaran tematik dengan mengangkat tema tema yang dekat dengan kehidupan siswa dan lingkungannya akan memberikan makna bagi siswa karena memenuhi kebutuhan, menarik minat, dan bakat siswa sehingga membantu dalam menyelesaikan pekerjaan atau bagi masa depan anak.

Berdasarkan penjelasan di atas, jelaslah bahwa minat memiliki pengaruh yang besar terhadap belajar atau kegiatan. Pelajaran yang menarik minat siswa lebih mudah dipelajari dan disimpan karena minat menambah kegiatan belajar. Untuk menambah minat seorang siswa di dalam menerima pelajaran di sekolah, siswa diharapkan dapat mengembangkan minat untuk melakukannya sendiri. Minat belajar yang telah dimiliki siswa merupakan salah satu faktor yang dapat memengaruhi hasil belajarnya. Apabila seseorang mempunyai minat yang tinggi terhadap sesuatu, akan terus berusaha untuk melakukan sehingga apa yang diinginkannya dapat tercapai.

Menarik minat belajar siswa yang baik dalam mempelajari tema maka dalam pembelajaran tematik harus diajarkan secara baik sesuai dengan standar isi. Keberhasilan guru dalam pembelajaran tematik sangat ditentukan oleh kompetensi atau kemampuan guru, di antaranya harus menguasai teori atau konsep tematik, metode pembelajaran tematik. Dengan mempunyai kompetensi tersebut, maka guru dalam melakukan proses belajar mengajar dapat mengarahkan siswa dengan baik.

Ada beberapa metode pembelajaran yang dapat digunakan dan diterapkan untuk pembelajaran tematik antara lain, metode Simon Berkata. Dalam penelitian ini peneliti memilih menggunakan metode Simon Berkata untuk meningkatkan minat siswa dalam pembelajaran tematik. Metode Simon Berkata merupakan salah satu jenis metode yang sering digunakan untuk mencairkan suasana penat dalam kegiatan belajar yang sekaligus sebagai hiburan, juga terbukti efektif untuk mengembalikan fokus dan konsentrasi siswa dalam belajar. Dalam metode Simon Berkata seorang siswa berperan sebagai Simon dan maju ke depan kelas. Setiap mengatakan Simon berkata "Silakan duduk" siswa lain menurutinya. Tetapi apabila Simon mengatakan "Simon" siswa lainnya tidak boleh mengikutinya. Kecermatan mendengarkan ucapan Simon menentukan pemberian reaksi yang tepat atau salah. Siswa yang salah mendapat hukuman.

\section{Metode Penelitian}

Pendekatan penelitian yang digunakan dalam penelitian ini adalah pendekatan kualitatif yang di teliti dengan jenis penelitian tindakan kelas (PTK). Teknik yang digunakan dalam penelitian ini adalah metode Simon Berkata dengan pendekatan kualitatif. 
Arikunto (2015 : 76) "hal yang di maksud dengan setting atau latar penelitian adalah keadaan lokasi tempat penelitian berlangsung, meliputi situasi fisik, keadaan siswa, suasana, serta hal - hal lain yang banyak berpengaruh terhadap tindakan yang dilakukan oleh guru ketika penelitian tindakan berlangsung" Tempat penelitian berada di SD Negeri 11 Sandung yang terletak di Desa Kelurahan Simba Raya Kecamatan Binjai Hulu Kabupaten Sintang, Provinsi Kalimantan Barat. Subjek penelitian adalah SD Negeri 11 Sandung di kelas IV dengan jumlah 11 siswa pada pembelajaran tematik selalu berhemat energi tahun pelajaran 2018 / 2019. Dalam penelitian ini yang menjadi objek penelitian adalah metode simon berkata yang merupakan variabel bebas $(\mathrm{x})$. Sumber data penelitian ini diperoleh melalui guru, siswa, data dokumen dan catatan lapangan.

Teknik pengumpulan data dilakukan dengan beberapa cara yakni observasi, angket (kuesioner), wawancara (interview), dan tes. Alat pengumpulan data dilakukan dengan beberapa cara yakni lembar observasi, lembar angket, pedoman wawancara, dan dokumentasi. Selanjutnya keabsahan data dalam penelitian ini adalah triangulasi. Triangulasi dilakukan pada triangulasi sumber berarti untuk mendapatkan data dari sumber yang berbeda - beda dengan teknik yang sama, dan triangulasi teknik menggunakan teknik pengumpulan data yang berbeda - beda untuk mendapatkan data dari sumber yang sama.

\section{Hasil Penelitian}

Penelitian Tindakan Kelas (PTK) dilaksanakan dalam dua siklus yaitu siklus I dan siklus II sampai siklus mencapai KKM dan ketuntasan klasikal. PTK dilaksanakan dalam empat tahap, yaitu perencanaan, pelaksanaan, observasi, dan refleksi. Untuk mengukur keberhasilan yang dilakukan, maka ditetapkan indikator - indikator kinerjanya baik adanya kesesuaian antara urutan penyajian materi dengan alokasi waktu pendekatan yang direncanakan, adanya perubahan yang terlibat dari sikap siswa, terutama keaktifan, keikutsertaan siswa dalam kelompok serta meningkatkan minat belajar siswa menjadi lebih baik.

\section{Siklus I}

\section{Perencanaan}

Pada tahap perencanaan bersama guru kelas IV, peneliti menerapkan Rencana Pelaksanaan Pembelajaran (RPP) yang mengacu pada tindakan yang diharapkan dalam PTK. Yang mana penelitian ini bertujuan meningkatkan minat dan prestasi belajar siswa pada pembelajaran tematik dengan menggunakan metode simon berkata. Selain itu, peneliti juga menyiapkan instrumen berupa lembar observasi untuk guru dan lembar observasi siswa, soal tes untuk mengukur minat belajar siswa dengan menggunakan metode simon berkata.

\section{Pelaksanaan Tindakan}

\section{Pertemuan I}

Pada tahap pelaksanaan pertemuan I, peneliti melaksanakan pembelajaran yaitu sebagai berikut : Guru memulai pembelajaran dengan mengucapkan salam, meminta ketua kelas untuk memimpin doa, melakukan kegiatan absensi siswa di kelas dengan jumlah siswa 11 orang hadir semua, menginformasikan materi pelajaran tentang sumber energi yang berkaitan dengan sumber energi yang berasal dari alam, guru menyampaikan tujuan pembelajaran yaitu siswa dapat mengidentifikasi sumber energi dari alam berdasarkan pengamatan melalui metode simon berkata, siswa mampu mendeskripsikan sumber - sumber energi dan manfaat masing - masing sumber energi melalui pengamatan dengan metode simon berkata, siswa mampu menyebutkan sumber - sumber energi saat ada kegiatan tanya jawab antara guru dan 
siswa. Guru meminta siswa menyiapkan alat tulis. Guru bertanya kepada siswa tentang materi yaitu tentang sumber - sumber energi yang akan dipelajari dengan tujuan menggali pengetahuan siswa, melalui jawaban siswa guru dapat memberikan penjelasan mengenai materi yang dipelajari, guru memberikan kesempatan kepada siswa untuk bertanya mengenai materi yang dibahas yaitu sumber - sumber energi. Guru membagikan siswa kedalam kelompok heterogen (4-5 orang) siswa, guru meminta siswa untuk duduk pada kelompoknya, guru meminta siswa untuk menyiapkan alat dan bahan yang diperlukan dalam kerja kelompok, guru menjelaskan kegiatan kelompok, guru membagikan lembar kerja siswa dan menjelaskan cara mengerjakan tugas kelompok di LKS di masing - masing kelompok. Setelah selesai mengerjakan tugas kelompok, guru meminta tiap - tiap kelompok untuk menyajikan hasil kerja kelompoknya ke depan kelas, guru bertanya kepada kelompok yang menyampaikan hasil kerja kelompok dan guru memberikan penilaian terhadap hasil kerja kelompok. Guru memberikan kesimpulan terhadap materi bagian sumber - sumber energi yang dipelajari dan mengaitkan dengan kehidupan siswa sehari - hari. Setelah selesai, guru meminta salah satu siswa untuk memimpin doa sebagai akhir dari pelajaran. Guru memberikan salam kepada siswa begitupun siswa juga memberikan salam kepada guru.

\section{Pertemuan /I}

Pada tahap pelaksanaan pertemuan II, peneliti melaksanaan pembelajaran yakni sebagai berikut: Guru memulai pembelajaran dengan mengucapkan salam, ketua kelas memimpin doa, melakukan kegiatan absensi dengan jumlah siswa 11 orang hadir semua. guru menginformasikan materi yang akan dipelajari yaitu tentang sumber daya alam Indonesia. Guru menyampaikan tujuan pembelajaran yaitu: siswa dapat mengindentifikasi sumber daya alam Indonesia berdasarkan pengamatan melalui metode pembelajaran Simon Berkata. Siswa mampu menyebutkan kembali sumber daya alam Indonesia dan bagian - bagian sumber daya alam Indonesia serta siswa mampu menyebutkan manfaat sumber daya alam Indonesia melalui pengalaman belajarnya dengan metode Simon Berkata. Guru bertanya kepada siswa tentang manfaat sumber daya alam Indonesia yang mereka ketahui. Melalui jawaban siswa, guru menjelaskan materi tentang manfaat sumber daya alam Indonesia. Guru membagikan siswa ke dalam kelompok heterogen (4-5 orang) siswa, guru meminta siswa untuk duduk pada kelompoknya, guru meminta siswa untuk menyiapkan alat dan bahan dalam mengerjakan tugas kelompok, guru menjelaskan cara kerja kelompok, guru memberikan lembar kerja siswa dan menjelaskan cara mengerjakan soal di LKS. Setelah selesai dikerjakan, guru meminta masing - masing kelompok atau perwakilannya membacakan hasil kerja kelompok mereka, dan guru memberikan penilaian. Guru menyimpulkan pelajaran tentang manfaat sumber daya alam Indonesia, guru mengaitkan materi itu dengan kehidupan sehari - hari siswa, guru meminta salah satu siswa untuk memimpin doa, guru mengucapkan salam kepada siswa, begitupun siswa mengucapkan salah pada guru.

\section{Observasi}

Pada tahap observasi, guru kelas IV sebagai observer melakukan pengamatan terhadap penerapan pembelajaran dengan metode simon berkata pada pembelajaran tematik tema selalu berhemat energi dilakukan peneliti di kelas IV dan mencatat setiap kegiatan serta perubahan yang terjadi pada guru mengajar. Observer mengamati setiap langkah - langkah guru mengajar menggunakan metode simon berkata serta mengamati langkah - langkah pembelajaran sesuai atau tidaknya dengan RPP yang dirancang. Kemudian, guru mengamati aktivitas siswa dalam mengikuti proses pembelajaran yang berlangsung. 
Observer menggunakan lembar observasi guru untuk melakukan pengamatan. Aktivitas guru pada siklus I menunjukkan angka dengan rata - rata sebesar $84.61 \%$. Hasil tersebut menunjukkan bahwa penggunaan metode Simon Berkata pada siklus I sudah berjalan sesuai dengan langkah tindakan. Hasil observasi aktivitas siswa pada siklus I, diperoleh dengan rata rata $76.92 \%$. Masih ada siswa yang belum merespon penerapan pembelajaran dengan metode simon berkata. Untuk mencapai hasil yang diharapkan, maka peneliti melanjutkan pada siklus II agar semua siswa dapat merespon penerapan pembelajaran dengan metode simon berkata.

\section{Refleksi}

Berdasarkan hasil penelitian tindakan yang dilaksanakan pada siklus I tentang peningkatan minat belajar siswa dengan menggunakan metode simon berkata pada pembelajaran tematik di kelas IV SDN 11 Sandung Kecamatan Simba Raya. Pada penelitian ini menggunakan lembar observasi guru dan siswa, lembar soal tes, wawancara guru dan siswa, dan angket minat belajar siswa terhadap penggunaan metode simon berkata. Dari refleksi siklus I diperoleh hasil sebagai berikut.

1. Hasil observasi aktivitas guru diperoleh rata - rata aktivitas guru pada siklus I sebesar 84.61 $\%$ dengan kriteria baik. Hal ini dikarenakan guru belum mengelompokkan siswa secara heterogen, guru belum mengelola waktu dengan efektif dan guru belum menerapkan metode simon berkata dengan maksimal.

2. Hasil observasi aktivitas siswa diperoleh rata - rata aktivitas siswa pada siklus I sebesar $76.92 \%$ dengan kriteria baik. Hal ini dikarenakan siswa belum terbiasa dengan metode yang diterapkan, siswa tidak terbiasa dalam belajar kelompok, serta masih ada beberapa siswa yang belum serius untuk belajar, dan siswa masih belum aktif bertanya kepada guru.

3. Hasil tes belajar menggunakan metode simon berkata pada siklus I sebesar $18.18 \%$ dengan kategori sangat rendah. Hal ini menunjukkan bahwa minat belajar siswa sangat rendah, serta rata - rata siswa tingkat belajar belum serius, dan siswa masih sulit untuk diatur dalam belajar baik secara individu maupun kelompok.

4. Hasil wawancara guru pada siklus I secara klasikal metode simon berkata telah dinyatakan baik dan layak digunakan dalam proses pembelajaran, dari sisi kognitif sangat berpengaruh terhadap kemajuan belajar siswa yang dianggap monoton, sehingga penggunaan metode simon berkata lebih menekankan pada kognitif siswa.

5. Hasil wawancara siswa pada siklus I rata - rata semua siswa merespon baik terhadap pembelajaran menggunakan metode simon berkata. Terlihat jelas selama proses pembelajaran siswa merasa antusias dan aktif terlibat berpartisipasi dalam belajar menggunakan metode Simon Berkata pada tema 2 selalu berhemat energi.

6. Hasil angket minat belajar siswa pada siklus I sebesar 89.54 dengan kriteria penilaian kuat. Hasil dari penyebaran angket siklus I, peneliti dapat mengukur sejauh mana minat siswa terhadap pembelajaran di dalam kelas. Dari hasil yang diperoleh menunjukkan adanya peningkatan belajar siswa menggunakan metode simon berkata.

\section{Pembahasan}

\section{Penggunaan Metode Simon Berkata pada Tema Selalu Berhemat Energi}

Metode Simon Berkata adalah sebuah metode atau cara pembelajaran di mana seorang siswa berperan sebagai Simon dan maju ke depan kelas. Setiap mengatakan Simon berkata "Silakan duduk" siswa lain menurutinya. Tetapi apabila Simon mengatakan "Simon" siswa 
lainnya tidak boleh mengikutinya. Kecermatan mendengarkan ucapan Simon menentukan pemberian reaksi yang tepat atau salah. Siswa yang salah mendapat hukuman. Penggunaan metode Simon Berkata pada tema selalu berhemat energi. Berdasarkan pembelajaran yang dilaksanakan pada siklus I dan II penggunaan metode Simon Berkata terbukti dapat meningkat minat belajar siswa, serta dapat dilihat dari hasil penyebaran angket siklus I dan II. Pada siklus I, angket minat belajar siswa diberikan setelah melaksanakan pembelajaran dengan metode Simon Berkata dengan memperoleh jumlah keterangan Ya 1790.82 dengan rata - rata 89.54 dengan kriteria penilaian kuat. Pada siklus II, angket minat belajar siswa memperoleh jumlah keterangan Ya 1809 dengan rata - rata 90.45 dengan kriteria penilaian kuat. Melihat kriteria penilaian yang kuat pada minat belajar siswa menyatakan bahwa setiap indikator minat seperti pemusatan perhatian dan pikiran, perasaan, kemauan telah dilaksanakan siswa dengan sangat baik. Hal ini membuktikan bahwa penggunaan metode Simon Berkata pada tema selalu berhemat energi dapat meningkatkan minat belajar siswa setelah guru menggunakan metode simon berkata.

\section{Peningkatan Minat Belajar Siswa}

Minat terhadap pembelajaran yang dimiliki seseorang bukan sebagai bawaan sejak lahir, tetapi dipelajari melalui proses penilaian kognitif dan penilaian afektif seseorang yang dinyatakan dalam sikap. Dengan kata lain, jika proses penilaian kognitif dan afektif seseorang terhadap objek minat adalah positif maka akan menghasilkan sikap yang positif dan dapat menimbulkan minat.

Hasil minat belajar siswa diukur menggunakan lembar angket. Berdasarkan lembar angket yang disebarkan kepada siswa kelas IV SDN 11 Sandung kecamatan Binjai Hulu, minat belajar siswa dilihat pada hasil angket siklus I dan siklus II yang disebarkan setelah akhir pembelajaran menggunakan metode simon berkata. Pada siklus I, angket minat belajar siswa diberikan setelah melaksanakan pembelajaran dengan metode simon berkata dengan memperoleh jumlah keterangan Ya 1790.82 dengan rata - rata 89.54 dengan kriteria penilaian kuat. Peneliti dalam memberikan angket kepada siswa melihat beberapa indikator yang dapat memicu minat belajar siswa, seperti pemusatan perhatian dan pikiran, perasaan, kemauan. Dalam hal ini, peneliti melihat indikator pemusatan perhatian dan pikiran terhadap pelajaran dengan metode simon berkata melalui proses kegiatan, ketertarikan, keterlibatan siswa selama proses belajar mengajar.

Pada siklus I untuk masing - masing indikator minat belajar siswa meliputi pemusatan perhatian dan pikiran, perasaan, kemauan dikategorikan baik dengan rata - rata minat siswa sebesar 89.54. Untuk indikator pemusatan perhatian dan pikiran siswa yang memicu minat belajar dapat dilihat melalui perhatian siswa dalam belajar dan pemberian tanggapan siswa terhadap subtema 1 sumber energi yang diajarkan. Namun, dalam hal memperhatikan dan memberikan tanggapan siswa dapat dikategorikan baik. Untuk indikator perasaan senang terhadap pembelajaran, siswa dalam proses pembelajaran berlangsung cukup antusias terhadap materi pembelajaran yang disampaikan oleh guru baik itu berupa memahami dan memperhatikan dalam proses belajar dikategorikan baik. Pemahaman siswa terhadap materi subtema 1 sumber energi bisa dikatakan cukup baik karena tidak semua siswa mudah memahami materi yang disampaikan. Hal ini disebabkan tingkat perhatian siswa tidak sepenuhnya terfokus pada materi pembelajaran yang disampaikan guru selama proses pembelajaran di dalam kelas. Untuk indikator kemauan atau kecenderungan pada diri siswa untuk terlibat aktif dalam pembelajaran serta untuk mendapat hasil yang terbaik dapat dilihat melalui partisipasi siswa selama proses kegiatan pembelajaran berlangsung dikelas terlihat 
jelas mana siswa yang aktif dan pasif baik dalam individu maupun kelompok, dalam indikator kemauan ini termasuk dalam kategori baik. Ketiga indikator inilah yang menjadi penilaian peneliti terhadap minat belajar siswa dan menjadi acuan peneliti dalam melihat minat belajar siswa. Sehingga pada siklus I ini minat belajar siswa dikategorikan baik dan perlu ditingkatkan.

Pada siklus II, angket minat belajar siswa memperoleh jumlah keterangan Ya 1809 dengan rata - rata 90.45 dengan kriteria penilaian kuat. Melihat kriteria penilaian yang kuat pada minat belajar siswa menyatakan bahwa setiap indikator minat seperti pemusatan perhatian dan pikiran, perasaan, kemauan telah dilaksanakan siswa dengan sangat baik. Hal ini membuktikan bahwa adanya peningkatan minat belajar siswa setelah guru menggunakan metode simon berkata.

Untuk menunjang penelitian yang dilakukan oleh peneliti maka peneliti harus memiliki sumber yang membuktikan bahwa minat belajar siswa dapat meningkat ketika guru menggunakan metode atau model pembelajaran yang bervariasi. Salah satu contoh penelitian yang menyatakan bahwa guru dapat meningkatkan minat belajar siswa yang berjudul, "The Use of 'Simon Says' Game: A Teaching Method of Total Physical Response (TPR) in Teaching English Vocabulary to Young Learners". Berdasarkan data yang diperoleh, nilai rata rata prates kelas eksperimen adalah 14.67 dan pasca-tes 17.83 sedangkan nilai rata-rata kelas kontrol pra-tes adalah 13.00 dan pasca-tes 9.67. Data hasil kuesioner pun menunjukkan bahwa mayoritas siswa memberikan respon positif.

\section{Respons Siswa Terhadap Pembelajaran Dengan Metode Simon Berkata}

Berdasarkan hasil wawancara siswa respon terhadap pembelajaran dengan metode simon berkata pada tema selalu berhemat energi di kelas IV SDN 11 Sandung terlihat respon siswa pada wawancara sangat baik. Pada saat pembelajaran berlangsung secara umum telah dapat memperhatikan dan berinteraksi dengan teman - teman di dalam kelas. Beberapa siswa juga sudah bisa menjawab soal dengan baik ketika diberikan pertanyaan oleh guru. Dilihat dari hasil wawancara siswa siklus I ke siklus II. Hal ini disebabkan oleh, pembelajaran yang dilaksanakan peneliti di dalam kelas mampu membuat siswa untuk berpartisipasi dalam pembelajaran. Selain itu, siswa juga sudah mulai memberikan tanggapan terhadap proses pembelajaran yang berlangsung dan siswa mengikuti pelajaran dengan baik. Untuk menunjang hasil respon yang diperoleh peneliti, maka peneliti harus memiliki sumber yang membuktikan aktivitas atau respon siswa meningkat yaitu pada penelitian yang berjudul "The Use of 'Simon Says' Game: A Teaching Method of Total Physical Response (TPR) in Teaching English Vocabulary to Young Learners". Berdasarkan data yang diperoleh, nilai rata rata pra-tes kelas eksperimen adalah 14.67 dan pasca-tes 17.83 sedangkan nilai rata-rata kelas kontrol pra-tes adalah 13.00 dan pasca-tes 9.67. Berdasarkan perhitungan uji hipotesis yang dilakukan dengan uji MannWhitney didapatkan nilai $P$ sebesar 0,000 yang lebih kecil daripada nilai alpha $(0,000<0,05)$. Penelitian ini membuktikan bahwa metode TPR yang menggunakan permainan 'Simon Says' efektif diterapkan dalam pembelajaran kosakata bahasa Inggris. Data hasil kuesioner pun menunjukkan bahwa mayoritas siswa memberikan respon positif terhadap penerapan metode TPR. Berdasarkan hasil penelitian, peneliti berharap guru Bahasa Inggris dapat menggunakan metode ini, sebagai salah satu alternatif dalam pengajaran kosakata Bahasa Inggris.

\section{Kesimpulan}

Berdasarkan hasil penelitian dan pembahasan, dapat disimpulkan bahwa penggunaan metode Simon Berkata pada tema selalu berhemat energi kelas IV SD Negeri 11 Sandung Tahun Pelajaran 2018/2019 sangat baik. Berdasarkan pembelajaran yang dilaksanakan pada 
siklus I dan II penggunaan metode Simon Berkata terbukti dapat meningkat minat belajar siswa. Serta dapat dilihat dari hasil penyebaran angket siklus I dan II. Pada siklus I, angket minat belajar siswa diberikan setelah melaksanakan pembelajaran dengan metode Simon Berkata dengan memperoleh jumlah keterangan Ya 1790.82 dengan rata - rata 89.54 dengan kriteria penilaian kuat. Pada siklus II, angket minat belajar siswa memperoleh jumlah keterangan Ya 1809 dengan rata - rata 90.45 dengan kriteria penilaian kuat. Hal ini membuktikan bahwa penggunaan metode Simon Berkata pada tema selalu berhemat energi dapat meningkatkan minat belajar siswa setelah guru menggunakan metode Simon Berkata.

Peningkatan minat belajar siswa setelah menggunakan pembelajaran dengan metode Simon Berkata pada tema selalu berhemat energi di kelas IV SDN 11 Sandung kecamatan Binjai Hulu Tahun Pelajaran 2018/2019 sangat baik. Hal ini didasarkan pada hasil angket minat yang disebarkan kepada siswa pada siklus I, siklus II. Pada siklus I angket minat belajar siswa diperoleh sebesar 1790.82 dengan rata - rata 89.54 dengan kriteria penilaian kuat. Sedangkan pada siklus II angket minat belajar siswa diperoleh sebesar 1809 dengan rata - rata 90.45 dengan kriteria penilaian kuat.

Respons siswa terhadap pembelajaran dengan metode Simon Berkata pada tema selalu berhemat energi di kelas IV SDN 11 Sandung Kecamatan Binjai Hulu Tahun Pelajaran 2018/2019 terlihat pada respons siswa pada wawancara siswa siklus I ke siklus II. sangat baik. Hal ini disebabkan oleh, pembelajaran yang dilaksanakan peneliti di dalam kelas mampu membuat siswa untuk berpartisipasi dalam pembelajaran. Selain itu, siswa juga sudah mulai memberikan tanggapan terhadap proses pembelajaran yang berlangsung dan siswa mengikuti pelajaran dengan baik. Dengan demikian, ada peningkatan respons siswa terhadap penerapan pembelajaran dengan metode Simon Berkata.

\section{Referensi}

Ahmadi, F. (2013). Meningkatkan Minat Membaca Siswa Sekolah Dasar dengan Metode Glenn Doman Berbasis Multimedia. Jurnal Penelitian Pendidikan, 27(1).

Akbar, S., et al. (2017). Implementasi Pembelajaran Tematik di Sekolah Dasar. Bandung: PT Remaja Rosdakarya.

Ariani, F., et al. (2009). Pembelajaran Mendengarkan. Jakarta: Jagakarsa.

Arikunto, S., et al. (2016). Penelitian Tindakan Kelas. Jakarta: PT Bumi Aksara.

Daryanto. (2014). Pendekatan Pembelajaran Saintifik. Yogyakarta: Gava Media.

Ginting, N. (2012). Meningkatkan Minat Belajar Siswa Dengan Menggunakan Model Pembelajaran Kooperatif Tipe Number Head Together (NHT) Pada Mata Pelajaran IPA Materi Pokok Gaya Magnet di Kelas V SD Tahun Pelajaran 2011/2012. Skripsi. Medan: Universitas Medan.

Hajar, I. (2013). Panduan Lengkap Kurikulum Tematik. Jogjakarta: Diva Press.

Hamdani. (2011). Strategi Belajar Mengajar. Bandung: Pustaka Setia.

Inawati, M. (2011). Meningkatkan Minat Mengenal Konsep Bilangan Melalui Metode Bermain

Alat Manipulatif. Jurnal Pendidikan Penabur, 16.

Amandara, P.I. (2016). The Use of 'Simon Says' Game: A Teaching Method of Total Physical Response (TPR) in Teaching English Vocabulary to Young Learners. Skripsi.

Bandung: Universitas Kristen Maranatha.

Moleong, L.J. (2017). Metodologi Penelitian Kualitatif. Bandung: PT Remaja Rosdakarya Kunandar. (2008). Langkah Mudah Penelitian Tindakan Kelas Sebagai Pengembangan Profesi Guru. Jakarta: PT Grafindo.

Majid, A. (2017). Pembelajaran Tematik Terpadu. Bandung: PT Rosdakarya. 
Polem, A.M. (2017). The Implementation Of Simon Say Game To Improve Students' Vocabulary Mastery In Learning English. Skripsi. Medan: Universitas Islam Negeri Sumatera Utara Medan.

Pratiwi, H. (2013). Peningkatan Minat Belajar Melalui Strategi Instant Assessment Dengan Media Choose Number Pada Mata Pelajaran IPS Siswa Kelas IV B SD Muhammadiyah 2 Kauman Surakarta Tahun Ajaran 2012/2013. Skripsi. Surakarta: Universitas Muhammadiyah Surakarta.

Sugiyono. (2016). Memahami Penelitian Kualitatif. Bandung: Alfabeta.

Suryabrata, S. (2016). Metodologi Penelitian. Jakarta: Rajawali Pers.

Hermanto, D.T. (2013). Peningkatan Minat Belajar Melalui Strategi Information Search Dalam Pembelajaran IPS Siswa Kelas IV SD Negeri Monggot 2 Geyer Grobogan Tahun Ajaran 2012/2013. Skripsi. Surakarta: Universitas Muhammadiyah Surakarta.

Wartini, S. (2012). Peningkatan Minat Belajar Seni Tari Melalui Hypnoteaching di SD Negeri 1 Prambanan Klaten Tahun pelajaran 2011/2012. Skripsi. Yogyakarta: Universitas Negeri Yogyakarta.

Winiarti. (2015). Penggunaan Permainan Simon Says/Simon Berkata Dalam Pembelajaran Bahasa Inggris untuk Anak Tunanetra. Skripsi. Bandung: Universitas Negeri Bandung. 